\title{
Financing and Mobilization of Revenue in Higher Educational Institutions: Evidence from Far-West Province, Nepal
}

\author{
Shiba Prasad Sapkota \\ Kailali Multiple Campus, Dhangadhi Kailali, Nepal \\ Email: Sheshank1981@gmail.com
}

How to cite this paper: Sapkota, S. P. (2021). Financing and Mobilization of Revenue in Higher Educational Institutions: Evidence from Far-West Province, Nepal. Creative Education, 12, 293-316. https://doi.org/10.4236/ce.2021.121021

Received: December 17, 2020

Accepted: January 26, 2021

Published: January 29, 2021

Copyright ( 2021 by author(s) and Scientific Research Publishing Inc. This work is licensed under the Creative Commons Attribution International License (CC BY 4.0).

http://creativecommons.org/licenses/by/4.0/

\section{(c) (i) Open Access}

\begin{abstract}
The study has employed a mixed method to analyze generation and mobilization of revenue in higher educational institutions, in the context of Far-west Provence considering three clusters; private campuses, community campuses and constituent campuses. It has analyzed the information in two separate sections; secondary data analysis and primary data analysis, then after the findings have been merged to draw conclusions. The correlation, regression and Granger Causality have been examined for the secondary data analysis and thematic discussion has been conducted for the primary data analysis. The analysis of secondary data shown that community campuses and QAA certified campuses have been heavily dependent on the students' contribution. Whereas, the constituent campuses have been depended on other institutional incomes. The efficiency of revenue mobilization has found a weak relationship with academic achievements. After a discussion with institutional heads, a new model of educational institution has been proposed.
\end{abstract}

\section{Keywords}

Higher Education Institutions, Ownership, Revenue Generation, Expenditure, And Relationship

\section{Background and Research Gap}

This study is mostly descriptive and analytical. Because it has examined and analyzed the secondary information. But in some cases, it has observed and discussed primary evidence. To some extent, it is explorative for instance, in the context of Far-west Provence, whether or not the ownership of the higher education institution influences the quality of education? Similarly, the discussion in 
the theme of whether higher education is the professional need or fundamental need and what additional features should be added to provide quality education in Far-west Provence could be an explorative idea.

Firstly, this study has analyzed the secondary information that what is the combination of revenue generation in the context of government-owned, community-owned, and privately-owned higher educational institutions. Similarly, in the context of QAA certified and QAA non-certified institutions, the same job has been done. Thereafter, how these institutions have been utilized the available revenue to increase the quality of higher education has been examined. The expenditure has been divided into capital natured as well as revenue natured and further divided into specific activities; library and internet, human resource development, seminar and workshop, academic publication and patents rights, training and workshop, employment generation, infrastructure development, and sports development. Then, the relationship and predictability have been examined considering the number of student pass-out as a dependent variable and different expenditure as independent variables. Similarly, the results have analyzed considering all the indicating variables as dependent and relevant variables as explaining variables for different cases.

Higher education is a professional need or fundamental need has found a debatable issue (Joshi, Saud, \& Rawat, Personal communication, January 9, 2020). In the context of Nepal, mainly three types of institutions; government-owned institutions, community-owned institutions, and privately-owned institutions have been contributing to provide higher education. The establishment of the universities has found different ownership and revenue generation system. If the example of Tribhuvan University is taken, infrastructure has been constructed by the government and 80 percent of the revenue has been contributed by the government and 20 percent of the revenue has been generated by the university itself. Tribhuvan University has been contributing around 90 percent of higher education services, with 61 constituent campuses and 1061 affiliated campuses (Tribhuvan University Bulletin, 2020). Considering the example of Far-west University and Mid-west University, sole responsibility for infrastructure development and operating revenue has been contributing by the government. If the example of Kathmandu University is taken, government has supported infrastructure construction and handed over to the local community. If the example of Pokhara University and Purbanchal University is taken, the government-supported for the infrastructure development and 20 percent revenue and 80 percent revenue is generated by the university themselves (Joshi, Personal communication, January 9, 2020). This implies that the government has established universities with different notions and principles. These universities have constituent campuses, affiliated community campuses, and affiliated private campuses. This evidence supported the argument that the Government of Nepal is not clear regarding the way of providing higher-level education. It has been formalized that based on the political pressure and leaders' intuitions rather than 
system and rules. Further, community-owned institutions and private institutions have been contributing to a large scale. The allocation of universities and constituent campuses is not rational. In some districts there are many constituent campuses but, in some districts, there is no single constituent campus. That might be due to the demography of the people. To draw a constructive conclusion regarding the ownership of the higher education institutions and need of education, two themes; "ownership of higher education institution" and "higher education is professional need or fundamental need" discussed with head of the higher education institutions clustering into three groups; government-owned, community-owned, and privately owned institutions. Finally, the higher education institutions' strengths, weaknesses, opportunities, and threats (SWOT) were discussed and suggestions are taken that should be improved to provide quality education.

The discussion with R. K. Saud, Personal communication, January 9, 2020 helped to conclude that an individual may not able to take an appropriate decision unless being free from mental stress. Further, most of the students of higher education are in between 18 to 28 years. In that age other physical development of the body also takes place. So, in this age being calm and stress less is a more complex phenomenon. Therefore, if we are talking about world-class education the stress less mind is compulsory. The yoga and meditation might be the instrument for releasing the stress. The incorporation of yoga and meditation in the education system could be a milestone to reform education system. The institutional initiation may take a long time to sift the traditional education system into a new proposed educational system. If the policymaker incorporates yoga and meditation in the teaching-learning pedagogy that might be more effective. The discussion with P. K. Joshi (Personal communication, January 9, 2020) enlists the modification of organizational culture to accommodate world-class education. The existing organizational culture, for instance, the government-owned institutions are the victims of political influence, lack of appropriate curriculum, feelings of supremacy, less research and development activities, individual interest is core rather than the organizational goal, and so on. Whereas there are opportunities like as less economic burden, new courses can be designed and developed, coordination with national and international institutions etc. Similarly, the private institutions have been putting their legs on two boats; the motto of the institution is to earn a profit, but they are fulfilling the social demand of higher education too. The privately-owned higher education institutions should be free from political and other hurdles. Then these institutions may able to exchange the quality of education at a reasonable price. But while visiting the nine educational institutions out of them two were found locked due to political pressure. This evidence supported that still, we are not perusing the ideology of "education is free from political and local level conflicts" in Far-west Provence. Community-owned institutions are suffering from the revenue generation and reduction of students in general education. These institutions are dependent on 
the university syllabus and are not getting preferred academic programs. Whereas, the community has been engaged in the development of such organizations. The inefficiency of the existing educational structure has demanded a new modality of the education system.

Community and university engagement in higher education services could be an efficient paradigm shift for the transformation of society and quality based needy education (Jackson, 2010). The scholarship, extracurricular activities, parents' education, age, previous result, and university have a significant influence on the academic performance of the student, but the part-time job has a moderate influence on the quality of higher education (Akareem, \& Hossain, 2016). The study of Tsinidou, Gerogianns \& Fitsilis (2010) argued that the relative weight of the determinant factors does influence the quality of higher education quality. In the United States of America, the rise of profit-making institutions particularly in degree-granting institutions has reported as a challenge to non-profit institutional hegemony. The paper has presented three related standards of research. First, it looked at the historical incorporation of degree-granting higher education institutions as a non-profit institution and the role of the state in the United States. Secondly, it has examined the researches on non-profit and for-profit institutions. Finally, it has presented initial findings on the growth of commercial in research universities and the implication of the growth. What emerges for higher education in the United States is a new paradigm? For the empirical analysis two-stages data were gathered; national level and institutional. The paper has found that there have been increased challenges in the hegemony of a non-profit institution (Pusser, 2000). This evidence showed that before 2000 $\mathrm{AD}$ the profit-making institutions have been taken place in the educational sector in the United States. This showed the trend in education in a developed nation. What kind of educational paradigms should be developed in the context of Nepal?

The study made by Jacobsen and Saultz (2012) argued that ownership of the local community is the more efficient and federal and central government can support the education system through policy and regulation. Education governance left primarily in the hand of local control boards. However, the state began to reassert its influence in educational policymaking. The federal government has expanded its role in education through programs, like no child left behind education. But as state and federal policymakers continue to increase their involvement in education policy, does the public support shift? The paper has examined the opinion from 1970 to $2010 \mathrm{AD}$, the result showed that the strong support to local control. At the same time, the state and the federal government can play an important role in education. When the issues and policies are appropriate there has been increasing support to the state and the federal government. This reference would be appropriate in the sense that now, the Government of Nepal has been entered into the federal system. Then the question regarding who should control education? It becomes a major issue for discussion. 
In China, higher education belonged to the public product. However, the Chinese Government gradually changing from fund investment to expenditure performance management. The evaluation of the expenditure performance system became the key point for the higher education investment mechanism reform. The study had examined the level, mechanism, and method of higher education expenditure performance evaluation and compared overall expenditure performance. The findings showed that expenditure performance evaluation is important for establishing the new higher education investment mechanism based on performance by enhancing the fund investment efficiency and promoting higher education development Wang (2009). The evidence could be relevant to the Nepalese context that the government has been financing to higher education through constituent campuses and to some extent through public campuses. How the campuses have been mobilizing revenues? And how it can be utilized effectively? Could be an issue for discussing and investigate.

The Government of Kenya has been spending 30 percent of its budget on education. It has been assumed that education has an important positive effect on economic growth but the evidence from Kenya has found very week. The study had aimed to examine the relationship between the amount of investing in education and the impact of the labor force in the economy. The study had examined the impact of physical capital formation on economic growth and to investigate the contribution of labor input on economic growth. The study had analyzed time-series data to establish the relationship between government education expenditure per worker and economic growth in Kenya during the period of 1967-2010. The data were collected from the Kenya National Bureau of Statistics and the World Bank. The study had used the multiplicative Cobb-Douglas production function where human capital was treated as an independent factor of production in the human capital augmented growth model. Unit root test and Granger-causality tests were carried out to make results adequate. The empirical results showed that education expenditure per worker has a positive significant impact on economic growth both in the long-run and short run. The cointegration estimate showed that a 1 percent increase in education per worker would rise by 0.5 percent in the labor force. Similarly, a one percent increase in fixed capital formation would increase by 0.15 percent in output and a one percent increase in labor would lead to a 0.21 percent decrease in output in the long run. The correlation result had shown that there was a positive relationship between investment in education and economic growth. Finally, the study has suggested that the private sector who has been benefited from such investment should increase the amount of investment in education (Otieno, 2016). This study could be relevant to support the methodology of this study and the concept that the school of thought of involvement of private sector investment in higher education.

A study conducted by Sapkota (2018) in the context of Far-west Provence that the effect of socio-cultural determinants on the academic performance of the students in higher education suggested that the academic performance of the 
students has been declined as the level gone up. Further, the socio-cultural determinants; ethnicity, gender, former royal family legacy, and genetic characteristics have no significant influence in academic performance. The educational institutions and the pedagogy of mentors could produce an equal result by providing a similar environment.

The corrected Least Square Dummy Variable (LSDV) model is appropriate to analyze the relationship of variables for the panel data (Judson \& Owen, 1996). Further, to examine the predictability of the variables Granger Causality Test has been used. This study has been considered the panel data for five years periods of nine institutions. Further, the study has used a thematic discussion approach of Braun \& Clarke (2006) to draw the conclusion of primary information. Though this methodology is a poorly demarcated approach. Therefore, a mixed approach and methodology have been used to discuss the results and it has merged the findings and attempted to conclude meaningful results of the issues; what is the condition of student contribution and other institutional sources of revenue generation of higher educational institutions in Far-west Province? Does the revenue of higher education institutions have been utilized effectively; in terms of infrastructure development, cost per student pass-out, human resource development, seminar, workshop, and training program, academic publication and sports program in Far-west Province? What are the major issues that should be addressed to enhance the quality of education in the Far-west province?

\section{Methodology}

This study has designed considering a mixed method. The qualitative information as well as quantitative information has been used. The fusion of the qualitative approach and quantitative can be made at the information level or the finding level. This study has merged at findings and discussion, then conclusions have drawn. The qualitative and quantitative information has been examined, described and analyzed. Hence, mostly it has used descriptive, analytical and causal-comparative methodology. To some extent it is explorative research; for instance, it has analyzed the influence of ownership in higher education institutions in the quality of education. The discussion regarding, whether higher education is the professional need or fundamental need in the context of Far-west Provence and the additional features that should be added to provide quality education could be explorative ideas. Regarding these issues, no literature has found in the context of Far-west Nepal, so far. Therefore, the study has designed considering a mixed approach as well as mixed methodology (Gujarati et al., 2012).

\subsection{Population and Sample}

In the Far-west Provence, 61 higher education institutions have been providing educational services. Which have been considered population of the study. For sampling purpose three clusters have been formed, government-owned, com- 
munity-owned and privately-owned higher education institutions. After forming the clusters, a purposive (judgmental) sampling method has been adopted. The reason behind that was all the higher educational institutions have no proper documentation system. Therefore, intentionally, the QAA certified institutions or the institutions which are in process of QAA have been selected, believing that these institutions have gone through the systematic process of documentation and the information could be obtained for the analysis. After analyzing the information considering government-owned, community-owned and privately-owned institutions. Further, the sampled institutions divided into QAA certified and QAA non-certified institutions for cross-validation of the findings. The samples of the study have presented in Table 1.

This study has employed descriptive and analytical research designs to deal with the fundamental issues associated with revenue generation and its mobilization in terms of employment generation, opportunity of getting education, infrastructure development, academic publication and patent right, human resource development, seminar and workshop, cost of education, facility of library and internet and sports development. Moreover, this study has used a causal-comparative research design to determine the effect of revenue mobilization. For the analysis of association between variables, the correlation has been employed. Further, the relationship has been examined by using the following regression model (Table 2).

The empirical work was based on panel data. Regression can then capture both variation on cross-section data, and variation over time. Another advantage of using panel data is that it allows for heterogeneity. Furthermore, the number of observations available when testing the stationary of the residual series in a level regression is greatly increased in a panel framework and this can substantially increase the explaining power of the determining variables. The first regression

Table 1. Sample of the study.

\begin{tabular}{|c|c|c|c|c|}
\hline SN & Name of Institution & $\begin{array}{c}\text { Type of } \\
\text { Institution }\end{array}$ & Date of Accreditation & Remarks \\
\hline 1 & $\begin{array}{c}\text { Central Campus of Far-Western } \\
\text { University }\end{array}$ & Government owned & - & Faculty of Management Far Western University \\
\hline 2 & Kailali Multiple Campus, Kailali & Community owned & $\begin{array}{c}29^{\text {th }} \text { May } 2012 \\
\text { Reaccredited in } 2018\end{array}$ & Affiliated community campus of Tribhuvan University \\
\hline 3 & Tikapur Multiple Campus, Kailali & Government owned & $30^{\text {th }}$ December, 2013 & Constituent campus of Far-western University \\
\hline 4 & Ghodaghodi Multiple Campus, Sukkhad & Community owned & $13^{\text {th }}$ January, 2020 & Affiliated community campus of Tribhuvan University \\
\hline 5 & Durga Laxmi Multiple Campus, Aatriya & Government owned & - & Constituent campus of Far-western university \\
\hline 6 & Kanchan Vidya Mandir, Kanchanpur & Community owned & $23^{\text {rd }}$ December, 2019 & Affiliated Community Campus of Tribhuvan University \\
\hline 7 & Sudurpaschimanchal Academy & Privately-owned & - & Private campus affiliate to Tribhuvan University \\
\hline 8 & $\begin{array}{l}\text { National Academy of Science and } \\
\text { Technology, Dhangadhi }\end{array}$ & Privately-owned & - & Private campus affiliate to Pokhara university \\
\hline 9 & Janjyoti Multiple Campus, Kanchanpur & Privately-owned & - & Private campus affiliate to Tribhuvan University \\
\hline
\end{tabular}


Table 2. Regression models.

\begin{tabular}{|c|c|c|}
\hline Model: 1 & $(\mathrm{TR})_{i t}=\beta_{0}+\beta_{1}(\mathrm{SC})_{i t}+\beta_{2}(\mathrm{OS})_{i t}+\beta_{3}(\mathrm{GD})_{i t}+u_{i t}$ & (i) \\
\hline Model: 2 & $(\mathrm{SP})_{i t}=\beta_{0}+\beta_{1}(\mathrm{TE})_{i t}+u_{i t}$ & (ii) \\
\hline Model: 3 & $(\mathrm{SP})_{i t}=\beta_{0}+\beta_{1}(\mathrm{SE})_{i t}+u_{i t}$ & (iii) \\
\hline Model: 4 & $(\mathrm{SP})_{i t}=\beta_{0}+\beta_{1}(\mathrm{CE})_{i t}+\beta_{2}(\mathrm{RE})_{i t}+u_{i t}$ & (iv) \\
\hline Model: 5 & $\begin{aligned}(\mathrm{SP})_{i t}= & \beta_{0}+\beta_{1}(\mathrm{LI})_{i t}+\beta_{2}(\mathrm{CPS})_{i t}+\beta_{3}(\mathrm{INF} . \mathrm{D})_{i t}+\beta_{4}(\mathrm{EMP} .)_{i t} \\
& +\beta_{5}(\mathrm{TW})_{i t}+\beta_{6}(\mathrm{APP})_{i t}+\beta_{7}(\mathrm{SD})_{i t}+u_{i t}\end{aligned}$ & (v) \\
\hline Model: 6 & $(\mathrm{EMP} .)_{i t}=\beta_{0}+\beta_{1}(\mathrm{SE})_{i t}+\beta_{2}(\mathrm{RE})_{i t}+u_{i t}$ & (vi) \\
\hline Model: 7 & $(\mathrm{LI})_{i t}=\beta_{0}+\beta_{1}(\mathrm{SE})_{i t}+\beta_{2}(\mathrm{RE})_{i t}+u_{i t}$ & (vii) \\
\hline Model: 8 & $(\mathrm{CPS})_{i t}=\beta_{0}+\beta_{1}(\mathrm{SP})_{i t}+\beta_{2}(\mathrm{SE})_{i t}+\beta_{3}(\mathrm{CE})_{i t}+\beta_{4}(\mathrm{RE})_{i t}+\beta_{5}(\mathrm{GD})_{i t}+u_{i t}$ & (viii) \\
\hline Model: 9 & $(\mathrm{INF} . \mathrm{D})_{i t}=\beta_{0}+\beta_{1}(\mathrm{SE})_{i t}+\beta_{2}(\mathrm{CE})_{i t}+u_{i t}$ & (ix) \\
\hline
\end{tabular}

Where, TR: Total revenue; EMP.: Employment; SC: Students' contribution; GD: Grants and donation; OS: Other institutional sources of income SP: Student passed; SE: Student enrolled; CE: Capital expenditure; RE: Revenue expenditure; LI: Library and internet; INF.D: Infrastructure development; CPS: Cost per student pass-out; SD: Sports development; $\beta$ : Slope; $u_{i t}$ Error term.

model has considered that total revenue as a dependent variable and students' fees, other institutional income generation and donation and charity as independent variables. Similarly, the regression model 2 has examined the relationship between student pass-out as a dependent variable and total expenditure as an independent variable. The regression model 3 has been examined the relationship between student pass-out as a dependent variable and student enrollment as an independent variable. The regression model 4 has been examined the relationship considering student pass-out as a dependent variable and capital expenditure and revenue expenditure as an independent variable. The regression model 5 has examined the relationship of student pass-out as independent variable and expenditure on library and internet, cost per student, infrastructure development, employment generation, training and workshop, academic publication and patent right, sports development and human resource development as independent variables. The regression model 6 examined the relationship of employment generation with student enrollment and revenue nature expenditure. The regression model 7 examined the relationship between library and internet with student enrollment and revenue natured expenditure. The regression model 8 examined the relationship of cost per student with student pass-out, student enrollment, revenue natured and capital natured expenditures. The regression model 9 examined the relationship of infrastructure development with student enrollment and capital nature expenditure.

\subsection{Granger Causality Test}

$\mathrm{H}_{0}$ : There does not exist causality in the regression model.

$\mathrm{H}_{1}: \mathrm{H}_{0}$ is false

\section{Unrestricted Model:}




$$
\mathrm{PS}_{t}=\sum_{i=1}^{n} \alpha_{i} \mathrm{TE}_{t-i}+\sum_{i=1}^{n} \beta_{j} \mathrm{SP}_{t-j}+\varepsilon_{1 t}
$$

Restricted Model:

$$
\mathrm{SP}_{t}=\sum_{i=1}^{n} \beta_{j} \mathrm{SP}_{t-j}+\varepsilon_{2 t}
$$

Unrestricted Model:

$$
\mathrm{TR}_{t}=\sum_{i=1}^{n} \alpha_{i} \mathrm{SC}_{t-i}+\sum_{i=1}^{n} \beta_{j} \mathrm{TR}_{t-j}+\varepsilon_{1 t}
$$

Restricted Model:

$$
\mathrm{TR}_{t}=\sum_{i=1}^{n} \beta_{j} \mathrm{TR}_{t-j}+\varepsilon_{2 t}
$$

Unrestricted Model:

$$
\mathrm{TR}_{t}=\sum_{i=1}^{n} \alpha_{i} \mathrm{OI}_{t-i}+\sum_{i=1}^{n} \beta_{j} \mathrm{TR}_{t-j}+\varepsilon_{1 t}
$$

Restricted Model:

$$
\mathrm{TR}_{t}=\sum_{i=1}^{n} \beta_{j} \mathrm{TR}_{t-j}+\varepsilon_{2 t}
$$

Unrestricted Model:

$$
\mathrm{TR}_{t}=\sum_{i=1}^{n} \alpha_{i} \mathrm{DC}_{t-i}+\sum_{i=1}^{n} \beta_{j} \mathrm{TR}_{t-j}+\varepsilon_{1 t}
$$

Restricted Model:

$$
\mathrm{TR}_{t}=\sum_{i=1}^{n} \beta_{j} \mathrm{TR}_{t-j}+\varepsilon_{2 t}
$$

Similarly, the causality of all the dependent and independent variables has been examined, whether there has been unidirectional or bidirectional or absence of causality in each cluster case of a different clusters. The causality test has been examined to analyze the predictability of the variables. As usual in the research activities, this study is not free from the limitations and delimitations. So, the reliability of the primary data depends on the responses provided by the respondents. This study has focused only on Far-west Province. Incorporation of other region's campuses would provide a brooder base. The study has covered only five years period. It would better to incorporate more but the information was not available. The study has incorporated the opinion of institutional heads only. It would better to incorporate the information of other stakeholders. The incorporation of information of private campuses may add the value of study. But this study has limited the secondary analysis of private campuses due to publicly unavailable have been some limitations of the study.

\section{Results and Discussions}

\subsection{Community Campuses}

The results from the evidence of community-owned higher education institutions have shown that more dependency on students' contribution, less dependency on other institutional incomes and no dependency on grants and donation. This finding implies that community-based higher education has been a self-sustained condition. It is better to shift the excessive dependency on the 
students' contribution to other sources of income. Where the employment generation ration has been less than the academically qualified human capital and that would have very less effect on economic growth as similar to the findings of Otieno (2016). This could be a very serious issue, where economic development has not backed by educational development. Such educational development might not be long-lasting.

Wang (2009) argued that performance-based educational investment should be made. The results from the community-owned higher education institutions shown that expenditure has been excessively made regardless of performance-based. This might create difficulty with goodwill and sustainability. The results have been shown that the larger enrollment of the students has been reducing the pass percentage. This could be due to as the educational level goes up the pass rate has been declined in the context of Far-west in line with the findings of Sapkota (2018). In another way round it should be looked at from the point of view of the university education system. Most of the general education programs (yearly based) have been a very low pass rate and low participation of the students. That could be other reasons for the low pass rate. The classification of total revenue into capital nature and revenue nature expenditure has shown insignificant relationships. The revenue nature expenditure has found more irrespective rather than capital nature expenditure. The argument of Wang (2009) could be relevant here that the expenditure should be performance-based. But still, the Government of Nepal is not clear about the polity of higher education (personal interview, B. D. Kafle, available, 01/16/2020, https://parisambad.com/2020/01/16/\%E0\%A4\%B5\%E0\%A4\%BF\%E0\%A4\%95\% E0\%A4\%B8\%E0\%A4\%BF\%E0\%A4\%A4-\%E0\%A4\%A6\%E0\%A5\%87\%E0\%A4\% B6\%E0\%A4\%95\%Е0\%A5\%8B-\%E0\%A4\%A4\%E0\%A5\%81\%E0\%A4\%B2\%E0\%A 4\%A8\%E0\%A4\%BE\%E0\%A4\%AE\%E0\%A4\%BE-\%E0\%A4\%B9\%E0\%A4\%BE\%E 0\%A4\%AE/?fbclid=IwAR1jLgl5Bj-Y9Jb4AR1PEV9tdEqJMLcD6bH1tEm6mHz6 v75XWts7nRTRTX4) in case of absence of clear policy of government regarding higher education institutions one step ahead monitoring and performance auditing of the community-owned institutions might be more complicated. But the ultimate solution to this issue is performance-based evaluation and feedback for improvement. In the case of the regulatory agency, UGC Nepal can initiate the novel work by adding a separate unit of performance-based audit every year of all higher education institutions. Another alternative to address the problem could be inter-organizational performance-based evaluation.

The relationship between the number of student pass-outs and library and employment generation have found satisfactory. Whereas, the relationship between the number of student pass-out and infrastructure development, sports development has been considerable. The improvement of sports development, as well as academic performance, can be made considering sports as a grade-based program. But the relationship of the number of students pass-out with cost per student, academic publication and training have found rather miserable. This 
has also been proved neither a single sampled institution has patent right reserved. The solution of academic work is more relevant for academic research. The cost-effectiveness can be improved through policy level or implementation level. The employment generation has not adequately maintained as per the enrollment of student and revenue expenditure. Therefore, the teacher and student ration have not maintained that has negatively influenced the performance of higher education institutions. This study has observed the relationship between employment generation and enrollment of the student. In the case of multiple campuses more rigorous study of the individual stream could be future research avenue. As possible shifting other revenue expenditure into employment generation or employment generation should be enhanced. The expenditure on the library has found irrational but this expenditure can be fruitful for the progress of educational institutions. As it has incorporated the evaluation criteria of QAA certification. So, the improvement of the library seems to be improved. The cost per student has not been significantly influenced by student enrollment, capital expenditure, revenue expenditure, student pass-out, and grants. This refers that students' fees have been increasing the irrespective number of student enrollment, student pass-out, donation, and charity. The findings are contrasting with the findings of Tsinidou, Gerogianns, \& Fitsilis (2010) that weighted value is significant to estimate student performance and cost. The infrastructure has been developed as per the student enrollment and capital nature expenditure made.

\subsection{Constituent Campus}

The student contribution, other institutional income, and support from the government have been significantly influenced the total revenue. The findings are in line with the conceptual framework. The combination of revenue generation seems sound in the contest of constituent campuses. The relationship between student enrollment and the student has found negative. From this finding, two analyses can be made; firstly, if the campuses have shifted into a mass-based enrollment system to alight based enrollment and as the enrollment of the student decreased and the number of student pass-outs has increased that is good. But another way round if the number of students increased and the number of student pass-outs has decreased that is not good. As the evidence supported that the campuses have been in the condition of the first alternate because these campuses have become the constituent campus of Far Western University before that they were affiliated campus of Tribhuvan University. In the case of the relationship between total expenditure and student pass-out, the negative relationship has been found this implies that as the total expenditure has increased the number of student pass-outs has decreased. The finding has found in line with the findings of Sapkota (2018) that in Far-west Provence as the level of student goes up the pass percentage of the student and marks have been decreased. The capital nature and revenue nature expenses have shown a negative relationship with student pass-out. This implies that the expenditure has not been utilized for 
the academic improvement of the student. The expenditure on the library has not significantly influenced the academic performance of the students. So, sufficient investment should be made and enhance to the student for the effective utilization of it. The cost per student and student pass-out has a significant and negative relationship. So, as the cost per student should be minimized as possible and increase the number of student pass-out. The expenses in employment generation, training and workshop, academic publication and grants and support have insignificant relation with the academic performance of the student. These expenses should be shifted into the performance-based expenditure.

The employment generation has significantly influenced by student enrollment and revenue expenditure. The enrollment of students has a negative relationship. This indicated that as the enrollment of the students increased the number of employees has not increased in the same proportion. The major part of the revenue expenditure has spent on employment generation. From this evidence, it can be concluded that the revenue expenses have not sufficient. In the context of constituent campuses, the government support for the infrastructure. Hence these institutions have spent capital nature expenses on purchasing educational equipment rather than the construction of the building.

\subsection{QAA Certified Campuses}

Highly depended on student contribution and continuous generation of other institutional income, and grants. The relationship between total expenditure and student pass-out has found insignificant and negative. This implies that the total expenditure has not proportional to the student pas-out. Further, the relationship has found negative. The negative relationship indicated that as the enrollment of the student increased but the proportional pass-out has decreased. This very serious fact that as enrollment of student has increased, expenditure has also increased but the number of student pass-outs has decreased. It indicates that inefficiency in operation of the higher educational institutions. The further conclusion has drawn based on this finding is that the contribution from the student, other institutional income and Grants have not been utilized efficiently. It has believed that the UGC Nepal has to regulate after certification of QAA that whether the higher educational institutions have been utilizing the revenue properly or not. But this evidence has raised the question in the monitoring activities of UGC Nepal. The classification of total expenditure into capital nature and revenue nature expenditure, both have insignificant relationship. The relationship of capital nature expenditure has positive, but revenue natured expenditure has found a negative relationship. This has indicated that the revenue expenditure has increased but the number of student pass-outs has decreased. This has indicated that the revenue expenditure has not spent properly. The enrollment of QAA certified institutions has increased but the number of student pass-outs has not increased proportionately.

The expenditure for the development of library, training and workshop, aca- 
demic publication and patent right has found ineffective for the academic performance of the students. Further, the grants and donations have not been utilized properly. The contribution of students has not been utilized properly. The major concern becomes here how these expenditures can be utilized effectively. The philosophy of management argued that effective monitoring and the controlling system might enhance effectiveness. So, a question of how cost-effectiveness and academic performance can be measured? and who should do this activity? The results have shown that there was a significant relationship between employment generation and revenue nature expenditure. Whereas, the employment generation has not sufficient as per the number of students enrolled as per the international teacher student ratio. The enhancement of the library has not consistent as per the enrollment of the student and revenue nature expenditure. The development of infrastructure has found good as the enrollment of the students and capital nature expenditure.

\subsection{QAA Non-Certified Campuses}

The combination of the QAA non-certified campus shown that it significantly depended on the contribution of students. If the campuses able to generate other sources of institutional income that would better. The proportionate pass-out number of students has not been increased as the expenditure increased. So, the campus has to focus on academic enhancement. As the enrollment of the student has increased the number of student pass-outs has decreased. This raised serious issues regarding academic improvement. The classification of total expenditure into revenue and capital nature has shown an insignificant relationship with the number of student pass-out. Further, the expenditure on the library, infrastructure development, employment generation, and grants have not found significant for the enhancement of the academic performance of the students.

The employment generation has found significant as per the student enrollment and revenue nature expenditure. This has indicated that the campus contributed by providing employment. The development of the library has found significantly inverse with an enrollment of the student and revenue natured expenditure. The development of infrastructure has found insufficient as per the enrollment of the student and capital nature expenditure. The improvement of the library, infrastructure development, and academic performance should be considerable issues (Table 3).

The revenue generation seems highly dependent on students' contributions in the context of community campuses and QAA certified. Whereas, in the context of constituent campuses other sources of institutional income have been found prominent. The grants and donations have been holding predicting power in the context of constituent campuses only. Regarding the predictability between the number of student pass-outs and total cost, it has found that only the total number of student pass-out has been holding the predictability towards changes in total cost. In the context of community campuses revenue nature expenditure has been holding explaining power and in the context of QAA certified 
Table 3. Summary regarding causal relationship.

\begin{tabular}{|c|c|c|c|c|}
\hline Causal relationship & $\begin{array}{l}\text { Community owned } \\
\text { campuses }\end{array}$ & $\begin{array}{l}\text { Constituent } \\
\text { campuses }\end{array}$ & $\begin{array}{l}\text { QAA certified } \\
\text { campuses }\end{array}$ & $\begin{array}{l}\text { QAA non-certified } \\
\text { campuses }\end{array}$ \\
\hline Total revenue and student contribution & $<>$ & 0 & $<>$ & NA \\
\hline Total revenue and other institutional incomes & 0 & $<>$ & 0 & NA \\
\hline Total revenue, and grants and donation & 0 & $>$ & 0 & NA \\
\hline Number of students pass-out and total expenditure & 0 & 0 & $<$ & NA \\
\hline Number of student pass-out and revenue expenditure & $>$ & 0 & $<$ & NA \\
\hline Number of student pass-out and capital nature expenditure & $<>$ & $<$ & $<$ & NA \\
\hline Number of student pass-out and number of student enrollment & 0 & $>$ & 0 & NA \\
\hline Number of student pass-out and library expenditure & 0 & 0 & 0 & NA \\
\hline Number of student pass-out and cost per student & 0 & 0 & 0 & NA \\
\hline Number of student pass-out and employment generation & $>$ & 0 & $<$ & NA \\
\hline Number of student pass-out and training and workshop & $>$ & 0 & 0 & NA \\
\hline Number of student pass-out and academic publication and patent right & $<$ & $<>$ & $<$ & NA \\
\hline Number of student pass-out and infrastructure development & 0 & $>$ & 0 & NA \\
\hline Employment generation and student enrollment & 0 & 0 & 0 & NA \\
\hline Employment generation and revenue nature expenditure & 0 & $<$ & 0 & NA \\
\hline Library expenditure and student enrollment & 0 & 0 & 0 & NA \\
\hline Library expenditure and revenue expenditure & 0 & $>$ & 0 & NA \\
\hline Infrastructure development and student enrollment & 0 & $>$ & 0 & NA \\
\hline
\end{tabular}

The symbol <>refers bidirectional causal relationship, $<$ or $>$ ( $<$ first variable causes latter variable and $>$ latter variable causes first variable) denotes unidirectional causal relationship, 0 stands for no causal relationship and NA refers information is not available.

campuses number of students, pass-out has been explaining the revenue expenditure. In the context of community campuses, both the variable capital nature expenditure and the number of student pass-out have been holding explaining power each other. But in the context of constituent and QAA certified campuses student pass-out has been holding explaining power to capital nature expenditure. The enrollment of the students and the number of student pass-out has found low predicting power in the context of community campuses and QAA certified campuses. In the context of constituent campuses, only the enrollment of the student has been holding explaining power regarding the number of student pass-out. Expenditure on the library and cost per student has been found low predicting power regarding the number of student pass-out in all the cases. Employ generation and number of student pass-out has found unidirectional causal relationship in the context of community and QAA certified campuses but no causal relationship in the context of constituent campuses. The causal relationship between the number of student pass-outs and training has found unidirectional in the context of public campuses only, otherwise low explaining power. The academic publication has found a bidirectional relationship 
in the context of constituent campuses and unidirectional in the context of community campuses and QAA certified. The causal relationship between the number of student pass-outs and infrastructure development has found low except constituent. Similarly, the weak causal relationship between employment generation and student enrollment, employment generation and revenue nature expenditure, library expenditure and student enrollment, and student enrollment and infrastructure development have observed. Finally, as the conceptual framework has presumed the relationship between variables has no combability.

The bidirectional causal relationship between total revenue and student contribution has found. This implies that both the variables have been holding predicting power each other. But no causal relationship has found with other institutional incomes and grants and donations. This indicated more dependency on institutions on the students' fees rather than other income-generating sources. The causal relationship between total revenue and other institutional incomes has found bidirectional.

\section{Primary Information Analysis}

Different tools and models are available for the interpretation of primary information. Thematic discussion approach (Braun \& Clarke, 2006) has employed for the study. This approach provides the opportunity of cross discussion plus the addition of experience and example of respondents. The psychology of respondents also an important thing while discussing the themes. The institutional heads have been considered as respondents for the study. Mainly, four themes; 1) whether higher education is the professional need or fundamental need? 2) Do ownership; government-owned, community-owned and privately-owned structures influence the quality of education? 3) SWOT analysis 4) what additional reforms should be made to provide quality of education in Far-West Provence have been discussed with all heads of the sampled institutions. This approach has weak demarcation but great insight regarding the issues (Table 4).

Table 4. Summary table regarding primary information analysis.

\begin{tabular}{|c|c|c|c|}
\hline Causal relationship & Community campuses & Constituent campuses & Private Campuses \\
\hline $\begin{array}{l}\text { Theme: } 1 \text { Higher level education is } \\
\text { professional need or fundamental } \\
\text { need. }\end{array}$ & Mixed & Professional need & Mixed \\
\hline $\begin{array}{l}\text { Theme: } 2 \text { Does the ownership of } \\
\text { educational institutions influence } \\
\text { quality of education or not. }\end{array}$ & Yes & Yes & Yes \\
\hline \multirow{4}{*}{ Theme: 3 SWOT analysis } & S: Community involvement & S: Financial support & S: Prompt decision \\
\hline & W: Political influence & W: Political influence & W: Employee turnover \\
\hline & O: Possibility of center for excellence. & O: Possibility of center for excellence. & O: Increasing belief \\
\hline & $\mathrm{T}:$ Dependency on student fees & $\mathrm{T}$ : Weak involvement of society & $\mathrm{T}$ : Government policy \\
\hline $\begin{array}{c}\text { Theme: } 4 \text { Improvement of } \\
\text { educational quality }\end{array}$ & $\begin{array}{l}\text { Meditation and sports should be } \\
\text { incorporated as credit course. Good } \\
\text { governance and organizational culture. }\end{array}$ & $\begin{array}{l}\text { Syllabus should be developed in such } \\
\text { a way that incorporate local issues } \\
\text { and global development. }\end{array}$ & $\begin{array}{l}\text { Institutional path should be clear. } \\
\text { Human resource development } \\
\text { should be encouraged. }\end{array}$ \\
\hline
\end{tabular}




\section{Conclusion}

The study has analyzed the revenue generation, expenditure and achievement of higher educational institutions in the context of Far-west province of Nepal. Based on the empirical evidences, it can be concluded that the campuses should reduce heavy dependency on student contributions. The educational institutions should make an effective expenditure. The educational institutions should establish a system of academic audit. The path of an educational institution should be clear. Political influence should be minimized. Involvement of society should be increased. Ownership should be handed over to the local community.

The government and the local community should jointly operate the educational institutions. Governance should be properly. The syllabus is better to incorporate local and global issues. Mental stability and physical fitness should enhance with academic courses. It is essential for the paradigm shift of the educational system.

\section{Recommendations}

\section{Community Campuses}

1. The excessive dependence on students' contributions should be shifted into other sources of income.

2. The educational institutions should have introduced such academic programs and policies which, enhance the economic development of the society.

3. The expenses should be performance-based.

4. Alight based enrollment of the students could be the solution of a lower passing rate.

5. The policy of the government regarding higher education should be clear and the provision of a performance-based academic audit should be compulsory.

6. The expenditure in the library and employment generation should be continued as per the student's need.

7. The grade-based elective course of sports should be offered.

8. The academic research-based activities should be done for the enhancement of educational improvement.

9. Either the university develops the policy of upgrading only the passed student in the next year or the educational institutions take responsibility for passing students on the same cost paid in particular year.

10. The other revenue expenditure should be shifted into employment generation as it is possible.

11. The standard of teacher and student ratio should be maintained.

12. Library improvement should be made.

13 Infrastructure has been constructed as per the need of students but whether these are constructed as university standards or not is a concerned matter.

\section{Constituent Campus}

1. The combination of total revenue is good in the context of constituent campuses. 
2. The total expenditure and student pass-out have found a negative relation, why happened so should be analyzed. If excess expenses have incurred that should be minimized as possible.

3. Alight based enrollment system increased the student pass-out that should be encouraged.

4. The expenditure should be a shift to the academic progress of the students.

5. The library and internet, training and workshop, employment generation, infrastructure, and grants and donations have to shift for the academic development of the students.

6. The cost per student should be minimized and the performance of the student should be enhanced.

7. The teacher and student ratio should be maintained.

8. The revenue expenditure should be increased and utilize for the professional enhancement of the student.

9. The infrastructure has found proportional to the enrollment of the student. It should be continued.

10. It seems more capital nature expenses have been spent for the purchase of educational equipment. If the infrastructure is sufficient that is good.

\section{QAA Certified Campuses}

1. The combination of total revenue has found well organized. So, better to its continuation.

2. The revenue has not utilized properly to enhance the academic performance of the students.

3. The monitoring agency should function properly.

4. The revenue expenses should be converted to meaningful expenditure.

5. Institutions should increase academic performance.

6. The educational institutions should evaluate how the library expenditure, training and workshop, academic publication and patent right, grants and donation, and students' contributions utilized effectively.

7. The culture of academic performance evaluation should be established and implement.

8. The reasons behind the mismatched between expenditure and academic performance should be identified.

9. The employment should consistently generate as per the student enrollments.

10. The library should be upgraded as per the need of students.

11. How the student contribution can be utilized properly for the enhancement of student academic enhancement should be analyzed.

12. The infrastructure development expenditure has found significant as per the enrollment of the students.

\section{QAA Non-Certified Campuses}

1. The dependency on student contribution greatly should be shifted into other income sources. 
2. The proportionate pass-out number of students should be increased as per the total expenditure increased.

3. The proportionate number of students pass-out should be increased proportionately as the enrolment of students.

4. The expenditure on the library, infrastructure development, employment generation, and grants has to utilize for the enhancement of the academic performance of the students.

5. The employment generation has found good as per the enrollment of the students.

6. The library should be improved.

7. The development of the infrastructure could be a considerable matter.

\section{Comprehensive Recommendations}

i. The campuses should reduce heavy dependency on student contributions.

ii. The educational institutions should make an effective expenditure.

iii. The educational institutions should establish a system of academic audit.

iv. The path of an educational institution should be clear.

v. Political influence should be minimized.

vi. Involvement of society should be increased

vii. Ownership should be handover to the local community.

viii. The government and the local community should jointly operate the educational institutions.

xi. Governance should be properly.

$\mathrm{x}$. The syllabus should incorporate local and global issues.

xi. Mental stability and physical fitness should enhance with academic courses.

xii. It is essential for the paradigm shift of the educational system.

\section{Conflicts of Interest}

The author declares no conflicts of interest regarding the publication of this paper.

\section{References}

(2020). Tribhuvan University (Online). http://tribhuvan-university.edu.np/wp-content/uploads/2019/06/Falgun-2075.pdf

Akareem, H. S., \& Hossain, S. S. (2016). Determinants of Education Quality: What Makes Students' Perception Different? Open Review of Educational Research, 3, 52-67. https://doi.org/10.1080/23265507.2016.1155167

Braun, V., \& Clarke, V. (2006). Using Thematic Analysis in Psychology. Qualitative Research in Psychology, 3, 77-101. https://doi.org/10.1191/1478088706qp063oa

Gujarati, D., Porter, D., \& Gunasekar, S. (2012). Basic Econometrics. New Delhi: Mc Graw Hill.

Jackson, E. T. (2010). University Capital, Community Engagement, and Continuing Education: Blending Professional Development and Social Change. Canadian Journal of University Counting Education, 36, 1-13. https://doi.org/10.21225/D5C889

Jacobsen, R., \& Saultz, A. (2012). Trends: Who Should Control Education? The Education 
Policy Center at Michigan Stae University: Michigan State University, 23, 1-19.

Judson, R. A., \& Owen, A. L. (1996). Estimating Dynamic Panel Data Models: A Practical Guide for Macroeconomists. Washington: Federal Reserve Board of Governors. https://doi.org/10.2139/ssrn.1904

Otieno, O. D. (2016). Role of Education Investment on Economic Growth and Development in Kenya. Journal of Education and Practice: Kenya, 7, 68-81.

Pusser, B. (2000). The Role of the State in the Provision of Higher Education in the United States. Australian Universities' Review, 24-35.

Sapkota, S. P. (2018). Socio-Cultural Determinants of Academic Performance of the Students: Evidence from Province No. 7 of Nepal. International Journal of Science and Research: India, 7, 364-370. https://doi.org/10.2139/ssrn.3275165

Tsinidou, M., Gerogianns, V., \& Fitsilis, P. (2010). Evaluation of Factors That Determine Quality in Higher Education: An Empirical Study. Quality Assurance in Education, 18, 227-244. https://doi.org/10.1108/09684881011058669

Wang, D. (2009). The Evaluation of Higher Education Expenditure Performance and Investment Mechanism Reform. International Education Studies: China, 2, 18-24.

https://doi.org/10.5539/ies.v2n1p18 


\section{Appendix}

\section{Appendix 1. Respondents Profile}

\begin{tabular}{cccc}
\hline SN & Name of Organization & Designation & Nature of organization \\
\hline 1 & Durga Laxmi Multiple Campus & Campus Chief & Government Campus \\
2 & Ghodaghodi Multiple Campus & Campus Chief & Community Campus \\
3 & Janjyoti Multiple Campus & Asst. Campus Chief & Private Campus \\
4 & Kailali Multiple Campus & Campus Chief & Community Campus \\
5 & Kanchan Bidya Mandir Campus & Campus Chief & Community Campus \\
6 & National Academy of Science and Technology & Campus Chief & Private Campus \\
7 & Sudur Paschimanchal Academy & Campus Chief & Private Campus \\
8 & Sudur Paschimanchal University & Dean (Management) & Government \\
9 & Tikapur Multiple Campus & Campus Chief & Government Campus \\
\hline
\end{tabular}

\section{Appendix 2. Secondary Information}

\begin{tabular}{|c|c|c|c|c|c|c|c|c|c|}
\hline Year & ID & SE & SP & TR & IS & ES & GD & CPS & $\mathrm{TE}$ \\
\hline $2071 / 72$ & 1 & 865 & 178 & $10,265,315$ & $7,572,375$ & $1,722,940$ & 970,000 & NA & $12,230,157$ \\
\hline $2072 / 73$ & 1 & 744 & 185 & $12,577,873$ & $10,395,487$ & $1,292,386$ & 890,000 & NA & $11,309,071$ \\
\hline $2073 / 74$ & 1 & 1049 & 184 & $15,019,619$ & $12,676,040$ & $1,196,304$ & $1,147,275$ & NA & $13,230,045$ \\
\hline 2070/71 & 2 & NA & NA & $14,738,477$ & $14,420,142$ & 318,335 & NA & NA & $15,111,823$ \\
\hline $2071 / 72$ & 2 & 866 & NA & $14,658,421$ & $14,658,421$ & NA & $2,929,315$ & NA & $16,459,731$ \\
\hline $2072 / 73$ & 2 & 1184 & 126 & $15,752,758$ & $15,752,758$ & NA & $1,542,470$ & $260,178.28$ & $32,782,463$ \\
\hline $2073 / 74$ & 2 & 1115 & 70 & $22,109,994$ & $19,841,677$ & $2,268,317$ & $12,033,706$ & $294,162.76$ & $20,591,393$ \\
\hline $2074 / 75$ & 2 & NA & NA & $27,788,848$ & $20,928,382$ & $6,860,466$ & $5,589,848$ & NA & $24,160,731$ \\
\hline 2070/71 & 4 & 6658 & 522 & $120,944,773$ & $103,672,641$ & $11,323,155$ & $5,948,977$ & 141,056 & $73,631,281$ \\
\hline $2071 / 72$ & 4 & 5707 & 446 & $94,771,063$ & $84,203,318$ & $8,729,277$ & $1,838,468$ & 190,300 & $84,873,649$ \\
\hline $2072 / 73$ & 4 & 5580 & 655 & $127,610,802$ & $115,400,440$ & $10,980,362$ & $1,230,000$ & 146,611 & $96,030,041$ \\
\hline $2073 / 74$ & 4 & 5812 & 631 & $160,908,422$ & $146,295,889$ & $9,642,653$ & $4,969,880$ & 180,739 & $114,046,273$ \\
\hline $2074 / 75$ & 4 & 6008 & 398 & $200,327,812$ & $161,594,698$ & $25,974,169$ & $12,758,945$ & 326,203 & $129,828,898$ \\
\hline $2071 / 72$ & 5 & 563 & 28 & $7,505,365$ & $6,255,365$ & NA & $1,250,000$ & $272,336.96$ & $7,625,435$ \\
\hline $2072 / 73$ & 5 & 659 & 21 & $8,680,157$ & $6,130,157$ & NA & $2,550,000$ & $430,014.71$ & $9,030,309$ \\
\hline $2073 / 74$ & 5 & 749 & 70 & $8,292,242$ & $6,467,242$ & NA & $1,825,000$ & $145,291.43$ & $10,170,400$ \\
\hline $2074 / 75$ & 5 & 736 & 75 & $10,521,134$ & $9,242,919$ & $2,445,202$ & $1,278,215$ & $141,347.43$ & $10,601,057$ \\
\hline 2070/71 & 9 & 2437 & 177 & $55,347,424$ & $44,035,317$ & $10,262,107$ & $1,050,000$ & $206,764.53$ & $36,597,321$ \\
\hline $2071 / 72$ & 9 & 2137 & 147 & $30,086,094$ & $22,921,695$ & $6,114,399$ & $1,050,000$ & $230,646.44$ & $33,905,027$ \\
\hline $2072 / 73$ & 9 & 1754 & 238 & $34,351,395$ & $35,990,038$ & $5,349,097$ & $1,050,000$ & $151,218.65$ & $35,990,038$ \\
\hline $2073 / 74$ & 9 & 1794 & 146 & $40,533,827$ & $32,331,473$ & $5,012,760$ & $3,189,592$ & $263,202.98$ & $38,427,635$ \\
\hline $2074 / 75$ & 9 & 1670 & 138 & $48,752,965$ & $31,185,706$ & $5,103,885$ & $12,463,374$ & $403,383.36$ & $55,666,903$ \\
\hline
\end{tabular}




\begin{tabular}{|c|c|c|c|c|c|c|c|c|c|c|}
\hline Year & ID & $\mathrm{CE}$ & $\mathrm{RE}$ & SD & LI & INF. D & EMP. & $\mathrm{T} \& \mathrm{~W}$ & APP & PF \\
\hline $2071 / 72$ & 1 & 788,610 & $11,441,547$ & $1,964,842$ & 186,394 & 522,177 & $6,957,460$ & $\mathrm{Na}$ & NA & 575,753 \\
\hline $2072 / 73$ & 1 & $1,739,714$ & $9,569,357$ & $1,268,802$ & 223,687 & 252,400 & $4,569,170$ & NA & NA & 591,468 \\
\hline $2073 / 74$ & 1 & 385,645 & $12,844,400$ & $1,789,765$ & 43,328 & 334,717 & $9,048,057$ & NA & NA & 397,546 \\
\hline 2070/71 & 2 & NA & $15,111,823$ & 53,285 & NA & $2,030,555$ & $28,041,173$ & 511,922 & NA & $2,804,117.3$ \\
\hline $2071 / 72$ & 2 & $2,097,219$ & $14,362,512$ & 271,815 & 143,871 & 800,893 & $10,236,716$ & NA & NA & $1,023,671.6$ \\
\hline $2072 / 73$ & 2 & $13,087,723$ & $19,694,740$ & 62,550 & 247,850 & 965,009 & $11,773,235$ & NA & NA & $1,177,323.5$ \\
\hline $2073 / 74$ & 2 & $1,325,822$ & $19,265,571$ & 234,436 & 30,920 & 5,000 & $129,666,961$ & 7,000 & NA & $12,966,696.1$ \\
\hline $2074 / 75$ & 2 & $1,477,614$ & $3,628,117$ & 276,972 & 453,758 & $3,663,916$ & $14,480,658$ & NA & 449,490 & $1,448,065.8$ \\
\hline 2070/71 & 4 & $5,628,463$ & $68,002,818$ & 259 & $1,576,310$ & $19,163,015$ & $45,852,650$ & 7,200 & 160,000 & $2,141,345$ \\
\hline $2071 / 72$ & 4 & $6,306,633$ & $78,567,016$ & 145,212 & 452,024 & $2,633,702$ & $53,041,686$ & 341,287 & 35,500 & $1,637,078$ \\
\hline $2072 / 73$ & 4 & $16,971,172$ & $79,058,869$ & 164,059 & 853,141 & $3,133,958$ & $56,005,351$ & NA & $1,497,362$ & $5,728,735$ \\
\hline $2073 / 74$ & 4 & $15,292,115$ & $98,754,158$ & NA & 736,213 & $7,609,724$ & $79,200,364$ & NA & $1,635,587$ & $28,335,678$ \\
\hline $2074 / 75$ & 4 & $19,492,403$ & $110,336,495$ & 191,350 & 736,213 & $6,778,966$ & $88,059,531$ & NA & $2,076,776$ & $79,276,454$ \\
\hline $2071 / 72$ & 5 & $3,932,087$ & $3,693,348$ & NA & 350,152 & $2,050,000$ & $1,956,975$ & NA & NA & $195,697.5$ \\
\hline $2072 / 73$ & 5 & $3,464,794$ & $4,665,515$ & NA & $5,249,914$ & $1,280,961$ & $3,042,634$ & NA & NA & $304,263.4$ \\
\hline $2073 / 74$ & 5 & $2,655,466$ & $7,514,934$ & NA & 261,792 & $2,040,800$ & $4,348,793$ & NA & NA & $434,879.3$ \\
\hline $2074 / 75$ & 5 & $1,180,685$ & $9,420,372$ & NA & 94,384 & 622,844 & $6,317,885$ & NA & NA & $631,788.5$ \\
\hline $2070 / 71$ & 9 & $2,435,416$ & $36,597,321$ & 593,901 & 754,694 & $7,916,263$ & $17,093,048$ & 215,971 & 116,321 & $1,018,809$ \\
\hline $2071 / 72$ & 9 & $2,612,089$ & $33,905,027$ & 225,053 & 480,868 & 204,429 & $19,814,278$ & 483,766 & 87,500 & $1,103,656$ \\
\hline $2072 / 73$ & 9 & $2,527,659$ & $35,990,038$ & 126,488 & 875,765 & 793,774 & $24,373,642$ & 245,199 & 208,380 & $1,123,911$ \\
\hline $2073 / 74$ & 9 & $2,416,139$ & $38,427,635$ & 66,300 & 998,893 & $1,202,467$ & $28,497,275$ & 98,400 & 223,966 & $1,445,671$ \\
\hline $2074 / 75$ & 9 & $2,924,209$ & $55,666,903$ & 42,643 & 673,784 & $2,818,211$ & $44,114,827$ & 265,144 & 239,842 & $1,481,884$ \\
\hline
\end{tabular}

Sources: Audit reports, bulletins of Durgalaxmi Multiple Campus, Ghodaghodi Multiple Campus, Kailali Multiple Campus, Kanchan Bidhya Mandir Samudayik College and Tikapur Multiple Campus from 2070 to 2075.

\section{Appendix 3. Correlation between Variables}

\begin{tabular}{|c|c|c|c|c|c|c|c|c|c|c|c|c|c|c|c|c|c|}
\hline SET & SPT & TR & IS & ES & GD & CPS & $\mathrm{TE}$ & $\mathrm{CE}$ & $\mathrm{RE}$ & SD & LI & INFD & EMP & TW & APP & $\mathrm{PF}$ & \\
\hline \multirow[t]{11}{*}{1.00} & 0.93 & 0.93 & 0.94 & 0.78 & 0.25 & 0.16 & 0.92 & 0.71 & 0.93 & -0.26 & 0.07 & 0.49 & 0.58 & 0.13 & 0.67 & 0.52 & SET \\
\hline & 1.00 & 0.85 & 0.88 & 0.62 & 0.07 & -0.10 & 0.86 & 0.70 & 0.86 & -0.10 & -0.03 & 0.38 & 0.48 & 0.01 & 0.68 & 0.38 & SPT \\
\hline & & 1.00 & 0.82 & 0.90 & 0.44 & 0.23 & 0.98 & 0.82 & 0.96 & -0.25 & 0.07 & 0.33 & 0.63 & -0.07 & 0.87 & 0.75 & $\mathrm{TR}$ \\
\hline & & & 1.00 & 0.87 & 0.39 & 0.19 & 0.98 & 0.82 & 0.96 & -0.25 & 0.06 & 0.33 & 0.64 & -0.08 & 0.87 & 0.71 & IS \\
\hline & & & & 1.00 & 0.49 & 0.24 & 0.86 & 0.67 & 0.85 & -0.17 & 0.04 & 0.26 & 0.55 & 0.01 & 0.80 & 0.79 & ES \\
\hline & & & & & 1.00 & 0.49 & 0.44 & 0.28 & 0.43 & -0.24 & 0.03 & 0.15 & 0.72 & -0.17 & 0.41 & 0.60 & GD \\
\hline & & & & & & 1.00 & 0.28 & 0.32 & 0.30 & -0.54 & 0.52 & -0.04 & 0.34 & 0.04 & 0.18 & 0.28 & CPS \\
\hline & & & & & & & 1.00 & 0.84 & 0.99 & -0.29 & 0.04 & 0.24 & 0.64 & 0.01 & 0.85 & 0.69 & $\mathrm{TE}$ \\
\hline & & & & & & & & 1.00 & 0.77 & -0.30 & 0.08 & 0.06 & 0.47 & -0.26 & 0.85 & 0.69 & $\mathrm{CE}$ \\
\hline & & & & & & & & & 1.00 & -0.27 & 0.03 & 0.26 & 0.65 & 0.10 & 0.79 & 0.65 & $\mathrm{RE}$ \\
\hline & & & & & & & & & & 1.00 & -0.25 & -0.15 & -0.26 & -0.19 & -0.19 & -0.12 & SD \\
\hline
\end{tabular}




$\begin{array}{ccccccc}1.00 & 0.18 & -0.10 & -0.12 & 0.03 & -0.01 & \text { LI } \\ & 1.00 & 0.12 & -0.12 & -0.01 & -0.03 & \text { INFD } \\ & & 1.00 & 0.00 & 0.55 & 0.59 & \text { EMP } \\ & & 1.00 & -0.21 & -0.18 & \text { TW } \\ & & & 1.00 & 0.81 & \text { APP } \\ & & & & 1.00 & \text { PF }\end{array}$

\section{Appendix 4. Regression Results}

\subsection{Regression Results: Evidences from Community Campuses}

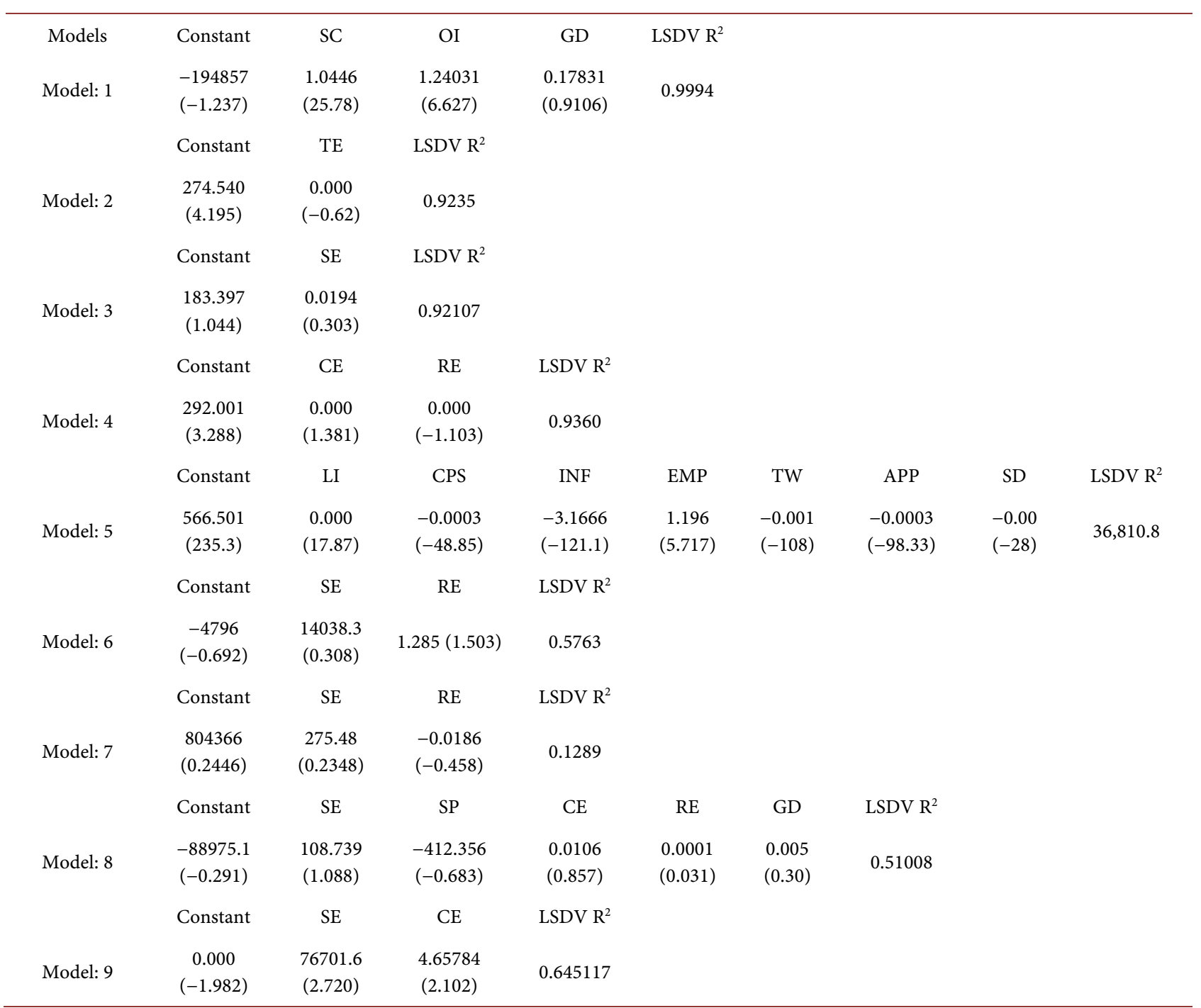

Sources: Audit reports, bulletins of, Ghodaghodi Multiple Campus, Kailali Multiple Campus, and Kanchan Bidhya Mandir Samudayik College from 2070 to 2075. 


\subsection{Regression Results: Evidences from Constituent Campuses}

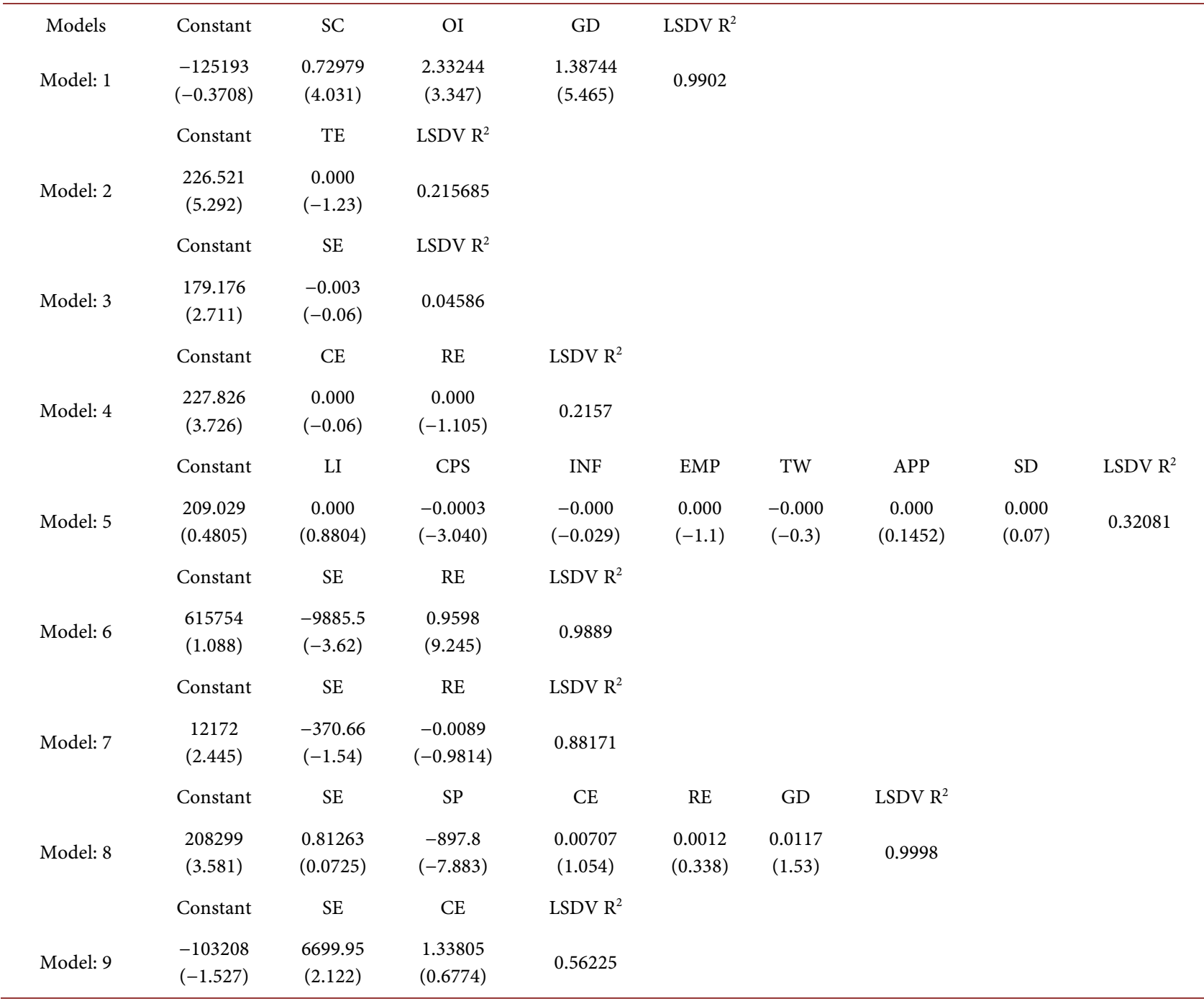

Sources: Audit reports, bulletins of Durgalaxmi Multiple Campus and Tikapur Multiple Campus from 2070 to 2075.

\subsection{Regression Results: Evidences from QAA Certified Campuses}

\begin{tabular}{cccccc}
\hline Models & Constant & SC & OI & GD & LSDV R $^{2}$ \\
& -105415 & 1.00562 & 1.03516 & 0.730632 & \\
Model:1 & $(-0.4489)$ & $(15.04)$ & $(3.752)$ & $(3.350)$ & 0.9979 \\
& Constant & TE & LSDV R & & \\
& 246.208 & -0.000 & & & \\
Model:2 & $(3.590)$ & $(-0.43)$ & 0.91518 & & \\
& Constant & SE & LSDV R & & \\
& 180.519 & 0.0147 & & & \\
Model:3 & $(1.419)$ & $(0.2937)$ & 0.91453 & & \\
& Constant & CE & RE & LSDV R & \\
& 277.82 & 0.000 & 0.000 & \multirow{2}{*}{0.930547} & \\
Model:4 & $(4.032)$ & $(1.621)$ & $(-1.371)$ & & \\
& & & & \\
\end{tabular}


Continued

\begin{tabular}{|c|c|c|c|c|c|c|c|c|c|}
\hline & Constant & LI & CPS & INF & EMP & TW & APP & SD & $\mathrm{LSDV}^{2}$ \\
\hline \multirow[t]{2}{*}{ Model:5 } & $\begin{array}{c}339.961 \\
(4.075)\end{array}$ & $\begin{array}{c}0.000 \\
(0.2659)\end{array}$ & $\begin{array}{l}-0.00029 \\
(-1.026)\end{array}$ & $\begin{array}{c}-0.000 \\
(-0.8679)\end{array}$ & $\begin{array}{l}0.000 \\
(0.22)\end{array}$ & $\begin{array}{l}-0.000 \\
(-1.0)\end{array}$ & $\begin{array}{c}-0.000 \\
(-0.585)\end{array}$ & $\begin{array}{l}-0.00 \\
(-0.7)\end{array}$ & 0.9393 \\
\hline & Constant & SE & $\mathrm{RE}$ & $\mathrm{LSDV}^{2}$ & & & & & \\
\hline \multirow[t]{2}{*}{ Model:6 } & $\begin{array}{c}-397664 \\
(-0.7633)\end{array}$ & $\begin{array}{l}9894.72 \\
(0.5349)\end{array}$ & $\begin{array}{l}1.3037 \\
(2.017)\end{array}$ & 0.58305 & & & & & \\
\hline & Constant & SE & $\mathrm{RE}$ & $\mathrm{LSDV}^{2}$ & & & & & \\
\hline \multirow[t]{2}{*}{ Model:7 } & $\begin{array}{c}106067 \\
(0.4299)\end{array}$ & $\begin{array}{l}124.012 \\
(0.1415)\end{array}$ & $\begin{array}{c}-0.0146 \\
(-0.4772)\end{array}$ & 0.12189 & & & & & \\
\hline & Constant & SE & SP & $\mathrm{CE}$ & $\mathrm{RE}$ & GD & $\mathrm{LSDV}^{2}$ & & \\
\hline \multirow[t]{2}{*}{ Model:8 } & $\begin{array}{c}5302.70 \\
(0.02364)\end{array}$ & $\begin{array}{l}69.311 \\
(1.038)\end{array}$ & $\begin{array}{l}-294.494 \\
(-0.6821)\end{array}$ & $\begin{array}{c}0.01081 \\
(1.096)\end{array}$ & $\begin{array}{l}-0.000 \\
(-0.02)\end{array}$ & $\begin{array}{l}0.0125 \\
(1.134)\end{array}$ & 0.5563 & & \\
\hline & Constant & SE & $\mathrm{CE}$ & $\mathrm{LSDV}^{2}$ & & & & & \\
\hline Model:9 & $\begin{array}{l}-111303 \\
(-1.971)\end{array}$ & $\begin{array}{l}62294 \\
(2.773)\end{array}$ & $\begin{array}{l}4.67002 \\
(2.366)\end{array}$ & 0.60152 & & & & & \\
\hline
\end{tabular}

Sources: Audit reports, bulletins of Durgalaxmi Multiple Campus, Ghodaghodi Multiple Campus, Kailali Multiple Campus, Kanchan Bidhya Mandir Samudayik College and Tikapur Multiple Campus from 2070 to 2075.

\subsection{Regression Results: Evidences from Non-QAA Certified Campuses}

\begin{tabular}{|c|c|c|c|c|c|c|c|c|c|}
\hline Models & Constant & SC & OI & GD & $\operatorname{LSDV}^{2}$ & & & & \\
\hline \multirow[t]{2}{*}{ Model:1 } & $\begin{array}{l}3.15036 \\
(4.225)\end{array}$ & $\begin{array}{c}0.92715 \\
(12.96)\end{array}$ & $\begin{array}{c}-7.91195 \\
(-2.600)\end{array}$ & $\begin{array}{l}12.3635 \\
(0.9395)\end{array}$ & 0.4688 & & & & \\
\hline & Constant & TE & $\mathrm{LSDV} \mathrm{R}^{2}$ & & & & & & \\
\hline \multirow[t]{2}{*}{ Model:2 } & $\begin{array}{c}187.577 \\
(0.01714)\end{array}$ & $\begin{array}{l}12.3635 \\
(0.9395)\end{array}$ & 0.468831 & & & & & & \\
\hline & Constant & SE & $\mathrm{LSDV} \mathrm{R}^{2}$ & & & & & & \\
\hline \multirow[t]{2}{*}{ Model:3 } & $\begin{array}{l}182.634 \\
(8.280)\end{array}$ & $\begin{array}{c}-0.0003 \\
(-0.01)\end{array}$ & 0.00018 & & & & & & \\
\hline & Constant & $\mathrm{CE}$ & $\mathrm{RE}$ & LSDV R $^{2}$ & & & & & \\
\hline \multirow[t]{2}{*}{ Model:4 } & $\begin{array}{l}180.460 \\
(31.50)\end{array}$ & $\begin{array}{c}-0.000 \\
(-0.378)\end{array}$ & $\begin{array}{c}-0.000 \\
(-0.2184)\end{array}$ & 0.12545 & & & & & \\
\hline & Constant & LI & CPS & INF & EMP & TW & APP & SD & $\mathrm{LSDV} \mathrm{R}^{2}$ \\
\hline \multirow[t]{2}{*}{ Model:5 } & $\begin{array}{l}183.492 \\
(27.67)\end{array}$ & $\begin{array}{l}-0.000 \\
(-0.19)\end{array}$ & NA & $\begin{array}{c}-0.000 \\
(-5.832)\end{array}$ & $\begin{array}{c}-0.000 \\
(-0.1)\end{array}$ & NA & NA & $\begin{array}{l}-0.00 \\
(-1.2)\end{array}$ & 0.613846 \\
\hline & Constant & SE & $\mathrm{RE}$ & LSDV R $^{2}$ & & & & & \\
\hline \multirow[t]{2}{*}{ Model:6 } & $\begin{array}{l}-59114 \\
(-2.895)\end{array}$ & $\begin{array}{l}14412.7 \\
(6.315)\end{array}$ & $\begin{array}{l}1.36260 \\
(22.61)\end{array}$ & 0.99804 & & & & & \\
\hline & Constant & SE & $\mathrm{RE}$ & LSDV R $^{2}$ & & & & & \\
\hline \multirow[t]{2}{*}{ Model:7 } & $\begin{array}{l}688577 \\
(6.017)\end{array}$ & $\begin{array}{c}-606.59 \\
(-4.74)\end{array}$ & $\begin{array}{l}-0.05316 \\
(-2.307)\end{array}$ & 0.84182 & & & & & \\
\hline & Constant & SE & SP & $\mathrm{CE}$ & $\mathrm{RE}$ & GD & $\mathrm{LSDV} \mathrm{R}^{2}$ & & \\
\hline \multirow[t]{2}{*}{ Model:8 } & NA & NA & NA & NA & NA & NA & NA & & \\
\hline & Constant & SE & $\mathrm{CE}$ & $\mathrm{LSDV} \mathrm{R}^{2}$ & & & & & \\
\hline Model:9 & $\begin{array}{c}224164 \\
(0.2830)\end{array}$ & $\begin{array}{l}164.335 \\
(0.1857)\end{array}$ & $\begin{array}{l}-0.10084 \\
(-0.5884)\end{array}$ & 0.25719 & & & & & \\
\hline
\end{tabular}

Sources: Audit reports, bulletins of Durgalaxmi Multiple Campus from 2070 to 2075. Sources: Audit reports, bulletins of Durgalaxmi Multiple Campus, Ghodaghodi Multiple Campus, Kailali Multiple Campus, Kanchan Bidhya Mandir Samudayik College and Tikapur Multiple Campus from 2070 to 2075. 